\title{
SOCIO-CULTURAL AND SOCIAL-ECONOMIC ANALYSIS OF PARENTS AND THEIR INFLUENCE ON LEARNING OUTCOMES OF CLASS VII STUDENTS OF SMP NEGERI 11 TANJUNGBALAI SCHOOL YEAR 2020/2021
}

\author{
Siti Fikriyah Bungsu Arief ${ }^{1}$; Ichwan Azhari²; ${ }^{2}$ asriah $^{3}$ \\ ${ }^{123}$ Universitas Negeri Medan \\ 3nasriah@unimed.ac.id
}

\begin{abstract}
Many factors can affect a student's success in learning, both internal and external factors, such as socio-cultural and economic parents of students. The study aims to analyze the socio-cultural conditions (family environment) and socio-economic conditions of parents (education, employment and parental income) and their effect on students' social study learning outcomes. From most of the socio-cultural conditions of students (family environments) are categorized well. The socio-cultural conditions of students have a significant effect on the learning outcomes of students' social studies with a value of $p=$ 0.004, in socio-economic conditions of the student's parents, most of whom have a low education, work as non-civil servants and the majority of the student's parents' income is relatively low. The education of the student's parents has a significant effect on the student's social studies learning outcomes. The work of the student's parents had a significant effect on the student's social study learning outcomes with a score of $p=0.016$. The income of the parents of students had a significant effect on the learning outcomes of social studies of students with a value of $p=0.017$, the results of a double logistic regression analysis concluded that the socio-cultural and educational conditions of parents were simultaneously a significant and dominant (strong) influence on social study learning outcomes for students of class VII of Tanjungbalai State Junior High School 11 Tanjungbalai school year 2020/2021.
\end{abstract}

Keywords: Social Culture, Socio-Economic Parents, Social Studies Learning Outcomes

\section{A. Introduction}

Education has a very important role to ensure the survival of the nation and state, because education is a forum or vehicle for improving and developing the quality of human resources. Education is one of the main factors for the development of 
human resources, because education is believed to be able to improve human resources so that it can create productive humans who are able to advance their nation. Education is also a form of national development to improve people's intelligence, so that an intelligent, advanced, and prosperous society can be realized. According to the Law of the Republic of Indonesia Number 20 of 2003, Chapter VI Article 6 concerning the National Education System it is explained that "every citizen aged seven to fifteen years must attend basic education". This is a form of effort to educate the community, namely the existence of a nine-year compulsory education program from Elementary School (SD) to Junior High School (SMP). The goal is that every citizen has the provision of knowledge and skills so that they have competitiveness in the competition in the era of globalization as it is today.

The 1945 Constitution article 31 paragraph 1 also states that every citizen has the right to obtain a proper education, in which the role of the government is obliged to pay for it. This indicates that an educator or teacher must also be aware that every student has the right to receive the same education and teaching regardless of religion, nation and ethnicity. Even though in their daily duties, a teacher is faced with a problem, namely that he must provide the same teaching to different students, both different from aspects of the social environment, ethnicity, culture, economy as well as the character and gender of the students.

The success of education and the success of students in learning is also a shared responsibility between families (parents), community members and the government. The government and society provide a place for learning, namely schools. The school accommodates students from various backgrounds or different social, cultural and economic conditions. The family (parents) is the first social institution known to the child and in this family attitudes can be instilled that can affect the child's further development. Families are responsible for providing funds for children's educational needs. Parents with high social, cultural and economic conditions will not experience much difficulty in meeting the school needs of their children, in contrast to parents whose social, cultural and economic conditions are low.

The quality of an education always refers to the achievements or learning outcomes achieved by students, as well as that one of the goals of students in school is to achieve maximum learning outcomes or achievements according to their abilities. The success or achievement of students in learning is basically influenced by many 
interrelated factors, both internal factors (from within students) and external factors (from outside students).

Internal factors that come from within students can be in the form of intelligence, attention, interests, talents, motivation, maturity, study habits and others. Meanwhile, external factors originating from outside the student can be in the form of the sociocultural environment (family, school and community), the economic conditions of parents, teachers and teaching methods, facilities, learning facilities and infrastructure, and so on. This also indicates that there is no single factor that stands alone, and automatically determines a person's success or achievement in learning.

However, among the factors mentioned above, the socio-cultural environment is one of the external factors that influence the success of children in learning. Socioculture is a characteristic pattern of behavior in a society in the form of habits, legal behavior, and social values that are adhered to and believed in in a group. Socio-culture is also the accumulation of knowledge, experience, beliefs, values, attitudes, meanings, hierarchies, religions, roles, broad concepts, and material objects that are owned and maintained by a group of people or a generation. (Fitria, 2016).

It is an undeniable fact that the Indonesian people and nation consist of various social diversity, ethnic groups, cultures, religions and so on so that Indonesian society can simply be called a multicultural society. On the other hand, this multicultural reality is faced with an urgent need to reconstruct Indonesian national culture or national culture which can become an integrating force that can bind all ethnic, ethnic and cultural diversity. (Kadir, 2012).

A conducive socio-cultural environment will affect student learning activities which have a positive impact on the achievement of learning outcomes. On the other hand, the tendency of students' poor socio-cultural environment has a negative impact on their learning outcomes. This is because the socio-cultural environment around students has a large enough role in the formation of their personality, where behavior and relationships as well as harmonization or conduciveness of the socio-cultural environment around students will be able to bring good and bad psychological effects on children's mental development and education.

Other external factors that can affect the success of children or students in learning are the socio-economic conditions of their parents. People who have a low socioeconomic level tend to have a low level of education as well. People still do not 
understand the importance of education, and still think that education is not a guarantee that they can live prosperously and far from poverty (Basrowi \& Juariyah, 2010).

The economic role of parents in general can be said to have a positive influence on increasing student achievement. This is because the teaching and learning process of students requires a tool or set of learning, where the tool is to facilitate students in obtaining information, managing learning materials obtained from schools. The socioeconomic situation of the family certainly affects the development of children (Chotimah et al., 2017). With a sufficient economy, the material environment faced by children in the family is wider, children have wider opportunities to develop various skills that cannot be developed if there is no infrastructure.

Education requires money, not only for tuition, but also for clothes, books, transport, extra-curricular activities and others. The problem of socio-economic conditions and parents' expectations for the future of their children, in the end will cause problems for parents in the form of a lack of parental attention to children's learning and the lack of parental income levels that allow the child to learn as little as possible. Most of the parents whose socio-economic conditions are low or include poor criteria (minimum or low income), also do not really expect their children to do well in school, and think that their children can go to school and can read and write is enough. This is because parents have not or are not even able to meet the needs of supporting facilities and infrastructure for their child's learning process. On the other hand, parents with high socio-economic conditions will have no difficulty in meeting their children's school needs because all the supporting facilities and infrastructure of the child's learning process can be met by their parents.

Tanjungbalai City, is one of the cities in North Sumatra Province which also has a multicultural community with various ethnicities, ethnicities, regional languages and religions and has various socio-economic levels. The people of Tanjungbalai city also send their children to public schools that have been provided and facilitated by the government. Public schools in Tanjungbalai City also have students from various sociocultural and economic backgrounds, one of which is SMP Negeri 11 Tanjungbalai.

The results of the initial observations of researchers at SMP Negeri 11 Tanjungbalai found that there were still many students who obtained social studies learning outcomes that had not been completed or were below the KKM score (KKM for social studies subjects was 65). Based on the Supplement to the Student Parent Book which contains a list of scores obtained from social studies teachers at SMP Negeri 11 Tanjungbalai, it shows that 
from 150 students (5 classes) there are 102 students (63.3\%) who have completed and as many as 48 students (36.7\%) unfinished. The results of the researchers' initial observations also found that students attending SMP Negeri 11 Tanjungbalai came from different sociocultural and economic backgrounds, both from ethnic or ethnic aspects (Malay, Toba Batak, Karo Batak, Mandailing, Javanese and Minang). religion (Islam, Protestantism and Catholicism), parental occupation (labor, private employee, fisherman, small sword,

Seeing the phenomena and problems described above, the researcher assumes that the learning outcomes obtained by students are influenced by many factors including socio-cultural factors (family environment) and family socio-economic factors (education level, occupation and parents' income). Therefore, researchers are motivated to conduct more in-depth studies and research by conducting research on the sociocultural and socio-economic analysis of parents and their impact on the learning outcomes of grade VII students at SMP Negeri 11 Tanjungbalai TA 2020/2021.

\section{B. Method}

This research is a type of field research using mixed or combined research methods. Mixed Methods Research is a research design based on philosophical assumptions as well as the method of inquiry. Mixed methods research is referred to as a methodology that provides philosophical assumptions in showing directions or providing instructions on how to collect data and analyze data as well as a combination of quantitative and qualitative approaches through several phases of the research process. This study uses a sequential explanatory design, namely a research design characterized by data collection and quantitative data analysis in the first stage, and followed by the collection and analysis of qualitative data in the second stage in order to strengthen the results of the quantitative research conducted in the first stage.

This study was used to analyze the socio-cultural and socio-economic conditions of parents and their impact on student learning outcomes. In the first stage of this research, quantitative research was conducted to provide an overview or explanation of the socio-cultural conditions (ethnicity and family environment) and socio-economic conditions of the parents (education level, livelihood, and income level of the parents). Meanwhile, the qualitative approach is to analyze what factors (socio-cultural and socioeconomic of parents) that have an impact or influence on social studies learning outcomes for seventh grade students of SMP Negeri 11 Tanjungbalai. 
The population of this study were all parents and seventh grade students of SMP Negeri 11 Tanjungbalai TA 2020/2021. The total student population is 5 classes and each class consists of 30 students so that the total student population in this study is 150 students. The sample in this study was taken as much as 30\% of the total student population or as many as 45 students and their parents. Determination of the sample in this study was carried out using the proportional random sampling technique (randomly proportions) that each class was taken as many as 9 students.

Data collection techniques and instruments used in this study were questionnaires and documentation studies. The data analysis technique used univariate, bivariate and multivariate analysis techniques. Bivariate analysis technique using Chi Square test $(\chi 2)$ and multivariate analysis technique using multiple logistic regression because the variables in this study are categorical scales. Data analysis using SPSS 16.0 program.

\section{Result and Discussions}

\section{Univariate Analysis}

Univariate analysis was carried out to describe the frequency distribution of research data including the characteristics of students who were the research sample (gender and ethnicity), data on students' socio-cultural conditions (family environment), socio-economic conditions of students including: education level, occupation and income of parents (father). , as well as data on student social studies learning outcomes obtained based on the pure value of the 2020/2021 Final Semester Final Examination (UAS) even TP on the cognitive (knowledge) aspect.

Table 1. Frequency Distribution of Student Characteristics

\begin{tabular}{clccc}
\hline \multirow{3}{*}{ Characteristics of Respondents } & Amount & Percentage (\%) \\
\hline \multirow{3}{*}{ Gender } & Man & 22 & 48.9 \\
& Woman & 23 & 51.1 \\
\cline { 2 - 5 } & & Amount & 45 & 100 \\
\hline \multirow{5}{*}{ ethnicity } & Malay & 8 & 17.8 \\
& Mandailing & 10 & 22.2 \\
& Toba Batak & 13 & 28.9 \\
& Java & 11 & 24.3 \\
& Minang & 2 & 4.4 \\
& Karo Batak & 1 & 2.2 \\
\cline { 2 - 4 } & & & 45 & 100 \\
\hline
\end{tabular}

Table 1, shows the characteristics of students by gender, the majority (51.1\%) of the students sampled in this study were female and the majority $(28.9 \%)$ of the students were of Toba Batak ethnicity. 
Table 2. Distribution of Socio-Cultural Frequency, Parents' Socio-Economic and Student Social Studies Learning Outcomes

\begin{tabular}{|c|c|c|c|c|}
\hline \multicolumn{2}{|c|}{ Variable } & Category & Amount & Percentage (\%) \\
\hline \multirow{3}{*}{\multicolumn{2}{|c|}{$\begin{array}{l}\text { Socio-Cultural (Family } \\
\text { Environment) }\end{array}$}} & Not good & 5 & 11.1 \\
\hline & & Good & 40 & 88.9 \\
\hline & & Amount & 45 & 100 \\
\hline \multirow{9}{*}{$\begin{array}{l}\text { Socio-Economic } \\
\text { Parents }\end{array}$} & \multirow{3}{*}{$\begin{array}{l}\text { Parental } \\
\text { Education }\end{array}$} & Low education & 28 & 62.2 \\
\hline & & higher education & 17 & 37.8 \\
\hline & & Amount & 45 & 100 \\
\hline & \multirow{3}{*}{ Parents' job } & Non civil servant & 41 & 91.1 \\
\hline & & civil servant & 4 & 8.9 \\
\hline & & Amount & 45 & 100 \\
\hline & \multirow{3}{*}{$\begin{array}{l}\text { Parent's } \\
\text { Income }\end{array}$} & Low & 39 & 86.7 \\
\hline & & Tall & 6 & 13.2 \\
\hline & & Amount & 45 & 100 \\
\hline \multirow{3}{*}{\multicolumn{2}{|c|}{ Social Studies Learning Outcomes }} & Not finished yet & 12 & 26.7 \\
\hline & & Complete & 33 & 73.3 \\
\hline & & Amount & 45 & 100 \\
\hline
\end{tabular}

Table 2, shows that the socio-cultural conditions (family environment) of the majority of students are in the good category (88.9\%), the socio-economic conditions of students, namely the education of the parents of the majority of students belong to the category of low education (62.2\%); the occupations of the majority of the students' parents are classified as non-civil servants (91.1\%); and the income of the majority of students' parents is low (86.7\%) and the data on social studies learning outcomes of the majority of students are classified as complete (73.3\%).

\section{Bivariate Analysis}

Bivariate analysis is intended to analyze the relationship or influence of sociocultural conditions (family environment) and socio-economic conditions of students (parents' education level, parents' occupations, and parents' income) on students' social studies learning outcomes. Bivariate analysis was performed using crosstabulations using the Pearson Chi Square ( $\chi 2)$ approach with the help of the SPSS program.

Table 3. The Influence of Socio-Cultural Conditions on Students' Social Studies Learning Outcomes

\begin{tabular}{|c|c|c|c|c|c|c|}
\hline & & \multicolumn{2}{|c|}{ Socio-cultural } & \multirow{2}{*}{ Total } & \multirow{2}{*}{$\begin{array}{c}\text { Pearson } \\
\text { Chi-Square }\end{array}$} & \multirow{2}{*}{ Sig } \\
\hline & & Not good & Good & & & \\
\hline \multirow{3}{*}{$\begin{array}{l}\text { Social } \\
\text { Studies } \\
\text { Learning } \\
\text { Outcomes }\end{array}$} & Not & 4 & 8 & 12 & \multirow{3}{*}{8.182} & \multirow{3}{*}{0.004} \\
\hline & Completed & $(8.9 \%)$ & $(17.8 \%)$ & $(26.7 \%)$ & & \\
\hline & Complete & $\begin{array}{c}1 \\
(2.2 \%)\end{array}$ & $\begin{array}{c}32 \\
(71.1 \%)\end{array}$ & $\begin{array}{c}33 \\
(73.3)\end{array}$ & & \\
\hline
\end{tabular}


Siti Fikriyah Bungsu Arief; Ichwan Azhari; Nasriah

\begin{tabular}{cccccc}
\hline & \multicolumn{2}{c}{ Socio-cultural } & \multirow{2}{*}{ Total } & Pearson & Sig \\
\cline { 2 - 3 } & Chot good & Good & & \\
\cline { 2 - 3 } Total & 5 & 40 & 45 & \\
& $(11.1 \%)$ & $(88.9 \%)$ & $(100 \%)$ & \\
\hline
\end{tabular}

Table 3 above shows the results of the cross tabulation between the data on the socio-cultural conditions (family environment) of students and the data on student social studies learning outcomes, from 5 students (11.1\%) whose socio-cultural conditions were classified as poor, there were 4 students (8.9\%) whose learning outcomes are classified as incomplete and as many as 1 student (2.2\%) who are classified as complete. Meanwhile, from 40 students (88.9\%) whose socio-cultural conditions were classified as good, there were 8 students (17.8\%) whose learning outcomes were classified as incomplete and as many as 32 students (71.1\%) who were classified as complete. Furthermore, based on the results of the analysis, the Pearson Chi-Square value is 8.182 with a probability value (Sig.) of 0.004 . Because the probability value (Sig.) is $0.004<0$, class VII SMP Negeri 11 Tanjungbalai TA 2020/2021.

Table 4. The Influence of Parents' Education on Students' Social Studies Learning Outcomes

\begin{tabular}{|c|c|c|c|c|c|c|}
\hline & \multicolumn{2}{|c|}{ Parental Education } & \multirow{2}{*}{ Total } & \multirow{2}{*}{$\begin{array}{c}\text { Pearson } \\
\text { Chi-Square }\end{array}$} & \multirow{2}{*}{ Sig } \\
\hline & & Low & Tall & & & \\
\hline \multirow{3}{*}{$\begin{array}{l}\text { Social } \\
\text { Studies } \\
\text { Learning } \\
\text { Outcomes }\end{array}$} & Not & 4 & 8 & 12 & \multirow{4}{*}{5,810} & \multirow{4}{*}{0.016} \\
\hline & Completed & $(8.9 \%)$ & $(17.8 \%)$ & $(26.7 \%)$ & & \\
\hline & Complete & $\begin{array}{c}24 \\
(53.3 \%)\end{array}$ & $\begin{array}{c}9 \\
(20.0 \%)\end{array}$ & $\begin{array}{c}33 \\
(73.3)\end{array}$ & & \\
\hline \multicolumn{2}{|c|}{ Total } & $\begin{array}{c}28 \\
(62.2 \%) \\
\end{array}$ & $\begin{array}{c}17 \\
(37.8 \%)\end{array}$ & $\begin{array}{c}45 \\
(100 \%) \\
\end{array}$ & & \\
\hline
\end{tabular}

Table 4 shows the results of the cross tabulation between the education data of parents (fathers) of students with data on student social studies learning outcomes, from 28 students (62.2\%) whose parents' education was low (graduated from elementary to junior high school) there were 4 students (8.9\%) whose learning outcomes are classified as incomplete and as many as 24 students (53.3\%) are classified as complete. Meanwhile, of the 17 students (37.8\%) whose parents' education was high (high school graduation to tertiary education), there were 8 students (17.8\%) whose learning outcomes were classified as incomplete and 9 students (20\%) who were classified as complete. Furthermore, based on the results of the analysis, the Pearson Chi-Square value is 5.810 with a probability value (Sig.) of $0.016<0.05$ so that statistically it is concluded that there is an influence of parental education (father) on students' social studies learning outcomes. class VII SMP Negeri 11 Tanjungbalai TA 2020/2021. 
Table 5. The Influence of Parents' Work on Students' Social Studies Learning Outcomes

\begin{tabular}{|c|c|c|c|c|c|c|}
\hline & & \multicolumn{2}{|c|}{ Parents' job } & \multirow[b]{2}{*}{ Total } & \multirow{2}{*}{$\begin{array}{c}\text { Pearson } \\
\text { Chi-Square }\end{array}$} & \multirow[b]{2}{*}{ Sig } \\
\hline & & $\begin{array}{c}\text { civil } \\
\text { servant }\end{array}$ & $\begin{array}{c}\text { Non civil } \\
\text { servant }\end{array}$ & & & \\
\hline \multirow{3}{*}{$\begin{array}{l}\text { Social } \\
\text { Studies } \\
\text { Learning } \\
\text { Outcomes }\end{array}$} & Not & 3 & 9 & 12 & \multirow{4}{*}{5,245} & \multirow{4}{*}{0.022} \\
\hline & Completed & $(6.7 \%)$ & $(20.0 \%)$ & $(26.7 \%)$ & & \\
\hline & Complete & $\begin{array}{c}1 \\
(2.2 \%) \\
\end{array}$ & $\begin{array}{c}32 \\
(71.1 \%) \\
\end{array}$ & $\begin{array}{c}33 \\
(73.3) \\
\end{array}$ & & \\
\hline \multicolumn{2}{|r|}{ Total } & $\begin{array}{c}4 \\
(8.9 \%)\end{array}$ & $\begin{array}{c}41 \\
(91.1 \%)\end{array}$ & $\begin{array}{c}45 \\
(100 \%)\end{array}$ & & \\
\hline
\end{tabular}

Based on the data in Table 4.11 above, it can be explained that the results of the cross tabulation between the work data of the parents (fathers) of students and the data on the social studies learning outcomes of students, out of 4 students (8.9\%) whose parents' occupations were classified as civil servants were 3 students $(6,7 \%)$ whose learning outcomes are classified as incomplete and as many as 1 student (2.2\%) who are classified as complete. Meanwhile, of the 41 students (91.1\%) whose parents' occupations were classified as non-civil servants, there were 9 students (20\%) whose learning outcomes were classified as incomplete and 32 students (71.1\%) who were classified as complete. Furthermore, based on the results of the analysis, the Pearson Chi-Square value is 5.245 with a probability value (Sig.) of $0.022<0.05$ so that statistically it can be concluded that there is an effect of parental (father) work on students' social studies learning outcomes. class VII SMP Negeri 11 Tanjungbalai TA 2020/2021.

Table 6. The Effect of Parents' Income on Students' Social Studies Learning Outcomes

\begin{tabular}{|c|c|c|c|c|c|c|}
\hline & & \multicolumn{2}{|c|}{ Parent's Income } & \multirow{2}{*}{ Total } & \multirow{2}{*}{$\begin{array}{c}\text { Pearson } \\
\text { Chi-Square }\end{array}$} & \multirow{2}{*}{ Sig } \\
\hline & & Low & Tall & & & \\
\hline \multirow{3}{*}{$\begin{array}{l}\text { Social } \\
\text { Studies } \\
\text { Learning } \\
\text { Outcomes }\end{array}$} & Not & 8 & 4 & 12 & \multirow{4}{*}{5,664} & \multirow{4}{*}{0.017} \\
\hline & Completed & $(17.8 \%)$ & $(8.9 \%)$ & $(26.7 \%)$ & & \\
\hline & Complete & $\begin{array}{c}31 \\
(68.9 \%)\end{array}$ & $\begin{array}{c}2 \\
(4.4 \%)\end{array}$ & $\begin{array}{c}33 \\
(73.3)\end{array}$ & & \\
\hline \multicolumn{2}{|c|}{ Total } & $\begin{array}{c}39 \\
(86.7 \%)\end{array}$ & $\begin{array}{c}6 \\
(13.3 \%)\end{array}$ & $\begin{array}{c}45 \\
(100 \%)\end{array}$ & & \\
\hline
\end{tabular}

Table 6 shows that the results of the cross tabulation between the income data of parents (fathers) of students and data on student social studies learning outcomes, from 39 students (86.7\%) whose parents' income is low (<Rp. 2,500,000,-/month ) there are as many as 8 students (17.8\%) whose learning outcomes are classified as incomplete and as many as 31 students (68.9\%) who are classified as complete. Meanwhile, from 6 students (13.3\%) whose parental income is high ( $\geq$ Rp. 2,500,000,-/month) there are 4 students (8.9\%) whose learning outcomes are classified as incomplete and 2 students 
$(4,4 \%)$ whose learning outcomes are classified as complete. Furthermore, based on the results of the analysis, the Pearson Chi-Square value is 5.664 with a probability value (Sig.) of $0.017<0$, class VII SMP Negeri 11 Tanjungbalai TA 2020/2021.

\section{Multivariate Analysis}

Multivariate analysis was conducted to determine the effect of the socio-cultural (family environment) and socio-economic conditions (education, employment and parental income) of students simultaneously (together) on the social studies learning outcomes of seventh grade students of SMP Negeri 11 Tanjungbalai TA 2020/2021. Because the data from each variable, especially student social studies learning outcomes data, uses dichotomous or binary categorical data, the multivariate analysis in this study was analyzed using multiple logistic regression tests with the help of the SPSS program.

Table 7. Hosmer and Lemeshow Test Results

\begin{tabular}{cccc}
\hline Step & Chi-Square & $d f$ & Sig. \\
\hline 1 & 0.543 & 3 & 0.909 \\
\hline
\end{tabular}

Based on Table 7, it can be explained that the results of the model suitability test using the Hosmer and Lemeshow Goodness of Fit Test technique obtained a Chi-Square value of 0.543 with a probability value (Sig.) of 0.909 . Because the probability value is $0.909>0.05$, then $\mathrm{Ho}$ is accepted so it can be concluded that the multiple logistic regression model used is appropriate to explain students' social studies learning outcomes with a $95 \%$ confidence level.

Table 8. Omnibus Test Results of Model Coefficients

\begin{tabular}{llccc}
\hline & & Chi-Square & $d f$ & Sig. \\
\hline Step 1 & Step & 15,078 & 4 & 0.005 \\
& Block & 15,078 & 4 & 0.005 \\
& Model & 15,078 & 4 & 0.005 \\
\hline
\end{tabular}

Based on Table 8 above, it can be explained that the results of simultaneous testing using the Omnibus Test of Model Coefficients obtained the Chi-Square model value of 15.078 with a Sig value. of $0.005<0.05$ which means $\mathrm{Ha}$ is accepted so it can be concluded that simultaneously socio-cultural conditions (family environment) and socio-economic (parental education, parents' occupations and parents' income) have a significant effect on social studies learning outcomes for seventh grade students of SMP Negeri 11 Tanjungbalai FY 2020/2021 or at least there is one independent variable that has a significant effect. 
The next stage is a partial test, to find out how many independent variables have a significant and dominant effect on students' social studies learning outcomes. Partial testing was carried out with the Wald test.

Table 9. Wald Test Results

Variables in the Equation

\begin{tabular}{llccccc}
\hline & & B & Wald & $d f$ & Sig. \\
\hline Step & Socio-Cultural Conditions & $-3,375$ & 1.393 & 5,872 & 1 & 0.015 \\
1 & Parental Education & 1,998 & 0.949 & 4,436 & 1 & 0.035 \\
& Parents' job & 0.881 & 2,155 & 0.167 & 1 & 0.683 \\
& Parent's Income & 1,593 & 1,670 & 0.910 & 1 & 0.340 \\
& Constant & -0.999 & 1,663 & 0.361 & 1 & 0.548 \\
\hline
\end{tabular}

Based on Table 9 above, it can be explained that the results of the partial test for the socio-cultural condition variable obtained a Wald value of 5.872 with a Sig. of 0.015 $<0.05$; the variable of parental education obtained a Wald value of 4.436 with a Sig value. of $0.035<0.05$; The variable of parents' occupation has a Wald value of 0.167 with a Sig value. of $0.0683>0.05$; and for the parental income variable, the Wald value obtained is 0.910 with a Sig value. of $0.340>0.05$. Thus, based on the results above, it can be concluded that socio-cultural (family environment) and socio-economic conditions, namely parental education, are significant and dominant (strong) factors or variables simultaneously influencing social studies learning outcomes for seventh grade students of SMP Negeri 11 Tanjungbalai FY 2020 /2021.

Table 10. Coefficient of Determination (Nagelkerke R Square)

\begin{tabular}{cccc}
\multicolumn{4}{c}{ Model Summary } \\
\hline Step & -2 Logs likelihood & Cox \& Snell R Square & Nagelkerke R Square \\
\hline 1 & 37,114 & 0.285 & 0.415 \\
\hline
\end{tabular}

Based on Table 10 above, it can be explained that the magnitude of the coefficient of determination in the logistic regression is shown by the Nagelkerke R Square value of 0.415, which means that the variable factors of socio-cultural and socio-economic conditions (education, occupation and income of parents of students) simultaneously and significantly have a significant effect on of $41.5 \%$ of the social studies learning outcomes of class VII students of SMP Negeri 11 Tanjungbalai for the 2020/2021 academic year.

\section{Discussion}


The socio-cultural environment is an environment that involves a student as a social being and interacts with that environment. For example the family environment, school environment, and community environment. Family environment is one of the factors that influence student success in learning. Family environmental factors can be in the form of the way parents educate, the relationship between family members in the house, tranquility in the family, and the socio-cultural background of the parents. The condition of the socio-cultural environment is one of the external factors that influence the success of children in learning. Socio-culture is a characteristic pattern of behavior in a society in the form of habits, legal behavior, and social values that are adhered to and believed in in a group. (Fitria, 2016).

The socio-cultural conditions of the students referred to in this study are the sociocultural conditions in the student's family environment obtained through a questionnaire with indicators including: the way parents educate, the relationship between children and family members (love, understanding, attention, and attitudes of family members). , as well as the atmosphere of the house (harmonious relationship, situation and condition of the house). The results of hypothesis testing indicate that there is an influence of socio-cultural conditions (family environment) on social studies learning outcomes for grade VII students of SMP Negeri 11 Tanjungbalai school year 2020/2021. Furthermore, based on the results of multivariate modeling on multiple logistic regression, it shows that simultaneously the socio-cultural condition of students is a dominant factor and has a significant effect on social studies learning outcomes for seventh grade students of SMP Negeri 11 Tanjungbalai TA.

The conclusion of the results of this study at the same time supports the Sociocultural theory by Vygostsky that "the way people live life is strongly influenced by the socio-cultural factors in which a person lives, this is no exception for students who most of the time their activities are in the school environment which is part of the community environment." (Fitria, 2016). The socio-cultural environment in social life, the environment in which a person lives will have an influence on behavior patterns, ways of thinking/views and a person's habits towards something. (Nurjannah \& Suhendra, 2015). Furthermore, the results of previous studies concluded that the family environment had a positive and significant effect on social studies learning outcomes for elementary school students (Sugiyanto, 2015), external factors that affect student learning outcomes and achievement include social factors, cultural factors and environmental factors (Shafi'i et al., 2018). 
The main purpose of national education is to educate the nation's life which is indicated by the level of education of its people. Education really needs an economic boost, it will be very difficult to give up education with economic factors. This linkage will underlie the relationship between socio-economic conditions and education. With varying levels of family economy, it will also significantly affect the level of education taken by children. Of course, this cannot be separated from parents' education, type of work and income level.

The economic role of parents in general can be said to have a positive influence on increasing student learning outcomes and achievement. This is because the teaching and learning process of students requires a tool or set of learning, where the tool is to facilitate students in obtaining information, managing learning materials obtained from schools. Parental education, economic status, residence, percentage of relationships, words, and parental guidance affect children's learning achievement (Chotimah et al., 2017).

Socio-economic conditions are a socially regulated position and place a person in a certain position in society or it can also be interpreted as a person's condition or position in the surrounding community. There are several aspects or factors that can determine the level of socioeconomic conditions in the community, including the level of education, type of work (livelihood), and level of income (income). The level of education, occupation and income of parents also determine the success of their children's education. Socio-economic referred to in this study is the condition of parents in the community based on the level of education, occupation, and income of parents of students.

The results of hypothesis testing concluded that there was an effect of parental education on social studies learning outcomes for grade VII students of SMP Negeri 11 Tanjungbalai FY 2020/2021. Furthermore, based on the results of multivariate modeling on multiple logistic regression, it shows that simultaneously the education factor of parents is a dominant factor and has a significant effect on social studies learning outcomes for grade VII students of SMP Negeri 11 Tanjungbalai TA 2020/2021.

Parental education, economic status, residence, percentage of relationships, words, and parental guidance affect children's learning achievement(Chotimah et al., 2017). The conclusion from the results of this study also supports the results of previous research by Umah which concluded that there was an influence of the level of parents' education on the learning outcomes of students' morals and beliefs. (Umah, 2019). 
The type of work or livelihood of parents is also one aspect or factor that determines the success of children's education in school. Parents should always look after and pay attention to the needs of their children, both primary needs and mental and social needs. The work referred to in this study is the type of work or livelihood of parents (fathers) who can make money to meet the needs of their family life. The occupations of parents in this study were grouped into 2 (two) groups, namely civil servants and non-civil servants.

Hypothesis testing results it can be concluded that there is an influence of parents' work on social studies learning outcomes for grade VII students of SMP Negeri 11 Tanjungbalai TA 2020/2021. Furthermore, based on the results of multivariate modeling on multiple logistic regression, it shows that the work of parents simultaneously is not a dominant factor influencing social studies learning outcomes for seventh grade students of SMP Negeri 11 Tanjungbalai TA 2020/2021. This means that simultaneously (simultaneously), the work of parents is not a factor that has a dominant (strong) influence on students' social studies learning outcomes or in other words, parents' work simultaneously has a weak influence on students' social studies learning outcomes.

Parent's occupation also determines income or income which is the result of work or business carried out. The income earned by parents is very necessary to meet daily needs and support the needs of children in learning. The size of the income or income of parents will affect the continuity of children's education, because education costs money. One's income varies from one person to another according to his work. Parents who have high incomes will be able to meet the needs of their children's educational and learning facilities and facilities, while parents with low incomes will have problems meeting their children's educational and learning needs.

The results of hypothesis testing are concluded that there is an effect of parental income on social studies learning outcomes for grade VII students of SMP Negeri 11 Tanjungbalai FY 2020/2021. Furthermore, based on the results of multivariate modeling on multiple logistic regression, it shows that simultaneously parents' income is not the dominant factor influencing social studies learning outcomes for seventh grade students of SMP Negeri 11 Tanjungbalai TA 2020/2021. This means that simultaneously (simultaneously), parents' income is not a factor that has a dominant (strong) influence on students' social studies learning outcomes or in other words, parents' incomes simultaneously have a weak influence on students' social studies learning outcomes. 
Based on the research findings related to socio-economic factors on student social studies learning outcomes as well as the results and bivariate analysis that has been carried out, it shows that socio-economic factors, namely parents' education, parents' occupations and parents' income have a significant effect on social studies learning outcomes for seventh grade students of SMP Negeri 11 Tanjung Balai. However, from the results of multivariate modeling analysis on linear logistic regression, socioeconomic factors that have a dominant (strong) influence on students' social studies learning outcomes are parents' education factors. While the factors of work and parents' income simultaneously have a weak influence on students' social studies learning outcomes.

The level of education of parents is considered the most influential factor on the level of education of children, because the higher the level of education of parents, the more positive their attitude towards the role of the school. This means that the level of parental education is correlated with a positive attitude towards education. Parents with a high level of education will have far-reaching insights about their children's education compared to those with low education. Parents who have high education also have great thoughts and encouragement to send and pay attention to their children's education. Thus, the education factor of parents is one of the most dominant (strong) factors in influencing their children's education, especially on the achievement of children's learning outcomes.

The results of the multivariate analysis on multiple logistic regression showed that the simultaneous work of parents was not a dominant (strong) factor on students' social studies learning outcomes or in other words, parents' work factors had a weak influence on students' social studies learning outcomes. This can be caused, because work is also closely related to time. Different types of work, of course, require different working hours. This also certainly affects the relationship between parents and children, especially parents' free time to guide and assist children in learning which also affects children's learning. Parents who are always busy with work, their attention to their children is greatly reduced. This can lead to physical growth, feelings, Children's intelligence and social skills are not good, resulting in reduced children's learning achievement. Parents who are not busy with work will devote a lot of attention to their children.

Furthermore, the results of multivariate modeling on multiple logistic regression also show that the income factor of parents simultaneously is not a dominant (strong) factor on students' social studies learning outcomes or in other words, parents' income 
factors have a weak influence on students' social studies learning outcomes. The factor of family income or parents also determines the success of children in achieving a higher level of education. In a family whose economy is less likely to cause children to be malnourished, the child's needs may not be met. However, this is not absolutely the case. Sometimes economic difficulties can be a driving force for children to be more successful, on the other hand it does not mean that excessive economics will not cause learning difficulties. In a superfluous economy,

The conclusions from the results of the analysis and research findings related to the influence of socio-economic conditions on students' social studies learning outcomes that have been carried out are also in line with and support the results of previous studies which generally conclude that the socioeconomic status of parents affects student learning outcomes and achievement. (Prabawa et al., 2014; Purnomo \& Rosalina, 2016; Chotimah et al., 2017; Utomo et al., 2018; Nafsia \& Harudu, 2019; Sidik, 2019; Johnson \& Sons, 2019).

\section{Conclusion}

Based on the research findings, data analysis and discussion, several conclusions were obtained, including:

1. The majority of the socio-cultural conditions (family environment) of the students who were sampled were categorized as good. The socio-cultural conditions of students have a significant effect on the social studies learning outcomes of class studentsVII SMP Negeri 11 Tanjungbalai school year 2020/2021.

2. The socio-economic conditions of the parents of the students who were sampled in this study were classified as low educated (elementary and junior high school graduates/equivalent), the majority worked as non-civil servants, especially entrepreneurs, and the majority of parents' incomes were categorized as low (less than Rp. 2,500,000,-/ month). The results of the bivariate analysis showed that:

a. The level of parental education has a significant effect on social studies learning outcomes for grade VII students of SMP Negeri 11 Tanjungbalai for the 2020/2021 academic year.

b. The work (livelihood) of parents has a significant effect on social studies learning outcomes for grade VII students of SMP Negeri 11 Tanjungbalai TA 2020/2021.

c. Parent's income has a significant effect on social studies learning outcomes for grade VII students of SMP Negeri 11 Tanjungbalai TA 2020/2021. 
3. The results of multivariate modeling analysis on logistic regression showed that socio-cultural conditions (family environment) and socio-economic conditions (education, occupation and income of students' parents) simultaneously and significantly gave $41.5 \%$ influence on social studies learning outcomes for seventh grade students of SMP Negeri 11 Tanjungbalai FY 2020/2021. The results of the analysis also show that socio-cultural factors (family environment) and parents' level of education are factors that have a dominant (strong) influence simultaneously (together) onSocial studies learning outcomes for seventh grade students of SMP Negeri 11 Tanjungbalai TA 2020/2021.

\section{Bibliography}

Basrowi, \& Juariyah, S. (2010). Analysis of Socio-Economic Conditions and Education Levels of the Srigading Village Community, Labuhan Maringgai District, East Lampung Regency. Journal of Economics \& Education, 7(1), 58-81.

Chotimah, LN, Ani, HM, \& Widodo, J. (2017). The Influence of Parents' Socio-Economic Status on Student Achievement (Case Study of Class VIII Students of SMP Negeri 1 Jember 2016/2017 Academic Year). Journal of Economic Education, 11(1), 75-80.

Fitria, Y. (2016). Student Attitudes towards Socio-Cultural Culture in Banyuwangi Regency (Descriptive Analysis Study). Asean Seminar, 2nd Psychology \& Humanity, 19-20.

Johnson, \& Anakampun, LEB (2019). The Influence of Socio-Economic Status and Parental Attention to Economic Learning Achievement of Class XI Social Sciences SMA Negeri Pakpak Bharat Regency FY 2017/2018. Journal of Educational Economics, 7(1), 45-56.

Kadir, A. (2012). The Influence of Socio-Cultural Conditions on Education and the Role of Education in National Cultural Development. Nuansa, Scientific Journal of Education, I(1), 25-48.

Nafsia, \& Harudu, L. (2019). The Effect of Parents' Socio-Economic Status on Geography Learning Achievement of Class IIS Students of SMA Negeri 3 Lapandewa, South Buton Regency. Journal of Geography Educational Research, 4(4), 1-6.

Nurjannah, \& Suhendra, R. (2015). Socio-Cultural Conditions Related to Children's Education in Fishing Communities in Perlis Brandan Barat Village. ANTHROPOS: Journal of Social and Cultural Anthropology, 1(2), 102-110.

Prabawa, KA, Dunia, IK, \& Haris, IA (2014). The Influence of Socio-Economic and Parental Attention to Economic Learning Achievement of Class X4 Students. Udiksha Journal of Economic Education, 4(1), 1-10.

Purnomo, B., \& Rosalina, A. (2016). The Influence of Parents' Socio-Economic Status on 
Student Achievement in Class IVB SD NO 64/1 Muara Bulian. Gentala Journal of Primary Education, 1(2), 275-297.

Sidik, R. (2019). The Influence of Parents' Social Status and Economic Conditions on Students' Social Studies Learning Achievement. Phinisi Integration Review, 2(2), 313-323.

Sugiyanto. (2015). The Influence of Learning Facilities, Family Environment, and Social Environment on Social Studies Learning Outcomes. PGRI Yogyakarta University National Seminar, 72-79.

Syafi'i, A., Marfiyanto, T., \& Rodiyah, SK (2018). Study of Student Achievement in Various Aspects and Influencing Factors. Journal of Educational Communication, 2(2), 115123.

Umah, F. (2019). The Influence of Social Environment and Parents' Education Level on Learning Outcomes of Akhlak in Class IV and V MIN 1 Gresik Students. Maulana Malik Ibrahim State Islamic University.

Utomo, SD, Adi, BW, \& Sunarto. (2018). The Influence of Parents' Socio-Economic Status and Learning Motivation on Entrepreneurial Cognitive Learning Outcomes in Class XI Students of SMK Kristen 1 Surakarta Academic Year 2017/2018. BIES: Journal of Business Education and Economics, 4(1), 1-10. 